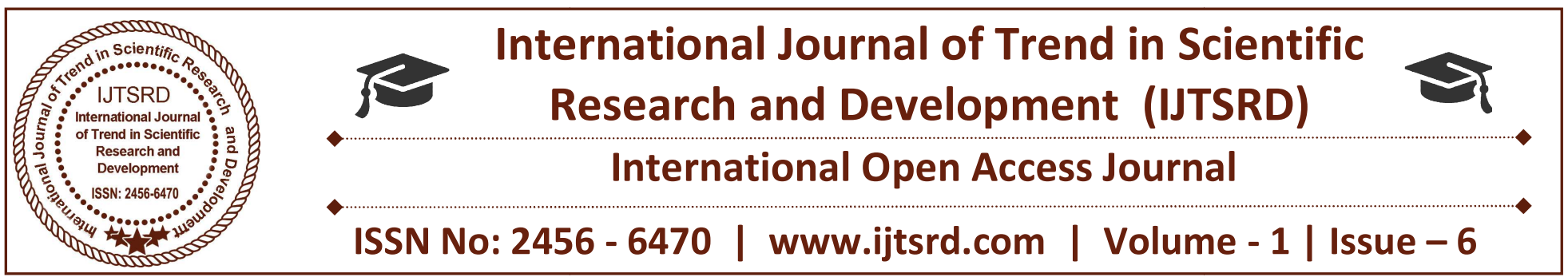

\title{
Unemployment, Commercial Motorcycle and Crime in Nigeria
}

\author{
Dr. Gbenemene Kpae \\ University of Port Harcourt, Rivers State, Nigeria
}

\author{
Dr. Eric Adishi \\ Novena University, Agume, Delta State, Nigeria
}

\begin{abstract}
Employment in Nigerian is pervasive and is further compound by the present economic recession in which many companies have downsized and increasing the number of unemployed. $\mathrm{r}$ millions of jobless and unskilled Nigerians. Driven by the hash economic climate many unemployed and unskilled Nigerians particularly youths have seen riding commercial motorcycle as a source of survival. Despite providing daily means for earning a living for many unemployed people, motorbikes have also become an instrument for committing crimes by many youths with high propensity for criminal behaviour. In many urban and rural areas where commercial motorcycles operate, motorbikes provide easy means for criminals to escape without police detection and apprehension. Many commercial motorcyclists have been involved in petty crimes such as hand bag and telephone snatching, and more dangerous crimes such as armed robbery, rapes, kidnapping and suicide bombing. This paper examines how unemployment propels jobless people into using commercial motorcycle to commit crime.
\end{abstract}

Keywords: unemployment, commercial motorcycle, crime

\section{INTRODUCTION}

The introduction of commercial motorcycles as a means of transport in many urban centres in Nigeria provided relieve too many unemployed persons who had been frustrated due to lack of jobs. Many jobless youths jumped into commercial motorcycle business to earn a living while some employed persons with low pay took to commercial motorbike business after work. In fact, due to youth restiveness, many states government have incorporate commercial motorcycles into their poverty alleviation and eradication scheme by procuring motorcycles to unemployed persons in their states (Mbalisi, and Nzokuru, 2014). However, rather than being a means of providing gainful employment for the unemployed, motorbikes have become an instrument for committing crimes. Many commercial motorcyclists who wants to make quick money use their motorbikes to snatch people handbags and rob them of their valuables. Since many of the inner streets and sub-urban areas are not too motorable, it is easy for some motorcyclists to commit crime and run away without being traced or apprehended by the police.

The alarming report of crimes with the use of motorbikes and the apparent inability of the law enforcement agencies to prevent and control its persistent and prevalence is still a major concern to many members of the public including the government. The advent of motorcycles as a means of public transport actually eased transportation problems in Nigeria. However, the abolition of commercial motorbikes in some urban centres in Nigeria due to their reported involvement in crime has not only compounded transport problems but has rendered many jobless. The pertinent question is, are all commercial motorcycle operators criminals? Not all commercial motorcyclists are criminals, but there is a general public perception that many of them, mostly youth riders, are involved in criminal activities. However, motorbikes have been linked to an increase in crime in cities throughout Nigeria, particularly city 
centres, urban slums and red light districts. The criminal activities range from theft of purses and mobile phones, grand larceny, suicide bombing and even politically motivated assassination. Due to the enormous criminal activities associated with commercial motorcycle, and the road accidents they cause, many people have called for its abolition.

\section{History of Commercial Motorcycle in Nigeria}

Commercial motorcycle gained popularity as a means of transport in Nigeria as far back as the early 1980's due to the collapse of public transport system and the failure of the Nigerian political leadership to create employment for her teeming population, and develop the country's infrastructure which include those facilities and systems necessary for the functioning of the community and the delivery of social welfare and other necessary essential services to the people of Nigeria (Kumar Ajay, 2013; Asekhamo, and Oiomoje, 2013). Thus, Nigerians in their millions took to 'okada' or commercial motorcycle riding, in order to earn a living and to get to their various destination. For instance, Michael Ojedoku and Chinwokwu (2013) contend that the proliferation of commercial motorcycles in urban centres is triggered by the unfriendly socio-economic policies which manifested in the high rate of urban unemployment, poverty and decayed social infrastructure. In addition to the high rate of joblessness experienced by low income people in urban centres, inadequate public transport system and the lucrative nature of the business to the poor has also forced many people into commercial motorcycle riding. In addition to unfriendly economic policies, commercial motorcycle multiplied in urban areas in Nigeria due to the Structural Adjustiment Programme (SAP) introduced by the Military head of state, General Ibrahim Babangida in 1986. SAP further worsened the socio-economic condition of many workers in urban centres across the country. As a result of the economic policy introduced by the military administration, many Nigerian workers lost their jobs through retrenchment and cost of vehicle importation skyrocketed while the rail system collapsed. This brought hardship on many citizens who now have to source for alternative means of survival and livelihood. Many of the workers, who lost their jobs due to SAP, took to commercial motorcycle operation in order to survive. This led to increase in the registered number of motorbikes for commercial purposes in Nigeria

\section{Commercial \\ Motorcycle \\ and \\ Economic Development}

The contribution of commercial motorcycle to the economic development of Nigeria cannot be overemphasized particularly in the provision of employment for jobless youths. As commercial motorcycles are becoming popular in major urban areas across Nigeria, there is also increase use of them by many passengers to commute to and from work. For example, in 1995 10,000 commercial motorcycles were registered in Lagos but by 2007 this number has jumped to 200,000 (Kumar Ajay, 2013). Similarly, Gbadamosi (2006) notes that 802 motorcycles were registered in Nigeria in 2001 and in 2002 the number of registered motorbikes has increased to 227,299. These figures show that the use of motorcycle as a means of public transportation has not only increased but has impacted significantly on the Nigerian economy. It has created business opportunities to millions of Nigerians, especially youths, retirees and retrenched persons. Apart from providing employment for jobless persons, many government workers have also engaged in commercial motorcycle business either as owners or actual riders to add to their meager wages. It is of note that some state governments have bought and distributed motorcycles to jobless youths part of their empowerment programmes and in line with the State Economic Empowerment and Development Strategy (NEEDS) policy in Nigeria.

Commercial motorcycles are used as a quick means of transport for a large number of people because it is cheaper and faster, especially its accessibility and capacity to maneuver bad roads and traffic congestions. Despite its benefits and positive impacts, the use of motorbikes as a means of transportation, commercial motorcycles have been used to commit various crimes especially bag snatching, pick pocketing, and armed robbery. It is estimated that more than $70 \%$ of crimes committed in Lagos are traceable to armed bandits riding on motorbikes. More importantly, most of the attacks on the Joint Task Force (JTF) trying to contain the Boko Haram sect in the northern part of Nigeria involve terrorists who ride on motorbikes (Michael, Ojedoku and Chinwokwu, 2013).

\section{Commercial Motorcycle and Criminal Activity}

Though the emergence of commercial motorcycle came as a big relief to many people and ease employment problem for many people, and also 
provided other advantages such as curbing loss of economic man hour, lateness to work, and other challenges associated with traffic jam which are very useful in a developing economy like Nigeria. Despite its tremendous benefits, in many urban areas motorbikes have become instruments for criminals, particularly armed robbers and purse snatchers who rob and escape through unmotorable track routes and dark alleys without easy apprehension by the police and other law enforcement agents (Mbalis and Nezokuru, 2014). Akogun (2008) observes that the problem with commercial motorcyclists is not that of recklessness and non-adherence to traffic rules, but that many of them have been indulging in criminal activities. This association between commercial motorcycles and criminal activities have led to public outcry for their abolition in many states across the country.

In response to the call by the public for abolition of commercial motorcycle as a means of transport, the government in various states in Nigeria (Cross Rivers State, and Rivers State, Edo state etc) passed laws outlawing the use of commercial on grounds of their alleged negative impacts on both grounds of accidents and criminal activities. In fact, the Rivers State government banned commercial motorcycle in Port Harcourt metropolis in 2008 and reinforced the ban in 2011. Following this ban, there was a reduction in the level of accident and crimes associated with commercial motorbikes.

\section{Methodology}

This paper relied mainly on secondary sources of data consisting of information obtained from academic journals, books, and internet materials.

\section{Theoretical Framework}

Since the early $18^{\text {th }}$ century criminologists such as Jeremy Bentham and Cesara Beccaria have attempted to explain the cause of criminal behavior. These early classical criminologists have argued that individual decisions were motivated by freewill. As a result punishment should be proportional and prompt in order to deter crime. The biological positivist criminologists especially in the work of Cesare Lombroso located criminality in the individual and contending that some individuals were simply born criminals. However, the social positivism school of thought rejected the biological or psychological explanation of criminal behavior and rather placed the cause of crime on environmental factors (Wikipedia, 2017).

The paper therefore uses Edwin Sutherland theory of Differential Association and Routine Activity Theories to examine how unemployment and commercial motorcycle leads to crime in Nigeria. Sutherland (1947) assumes that criminal behavior is learned through group association and interaction. More significantly, Sutherland delineates nine principles of differential association which explains the process by which a particular person comes to engage in criminal behavior. The most important of those nine principles is that a person only becomes delinquent when there is an excess definition favourable to violation of the law over definitions unfavourable to violation of law (See also Igbo, 1999; Iwarimie Jaja, 2012). Poverty and lack of employment in Nigeria have compelled many people especially jobless youths who are commercial motorcycle riders to join criminal gangs where in the process of the association and interactions with the criminal groups learn criminal behavior. Since many young people are driven by the desire to make quick money, commercial motorcycle provides that easy means to commit property crimes in hidden locations and to escape without arrest by law enforcement agencies. As many individuals use motorbikes to commute to and from work so they become vulnerable to attack and victimization from criminal gangs operating on commercial motorcycles.

Another theory that is suitable to situate the problem of crime by commercial motorbike operators is the Routine Activity Theory (RAT). The Routine Activity Theory by Cohen and Felson (1979) is one of the theories of environmental criminology. Theory assumes that crime is relatively unaffected by social causes such as poverty, inequality, unemployment.

The theory states that for a criminal event to occur there must be a convergence in time and space of three factors: these are the presence of a motivated offender, the absence of a capable guardian and the presence of a suitable target (person or object). Whether or not these elements converge or coincide is a product of the routine activities (day-to-day movement) of potential targets and offenders. Commercial motorcycle transporting business is part of the routine activities of offenders, suitable targets are passengers and the absence of capable guardians is the absence of men, security staff, and members of the public such as vigilante groups, friends and neighbours. Daily activities of people such as going to work, pursuing 
recreation and running errands brings offenders in contact with suitable victims and targets. In Nigeria most crimes committed by commercial motorcyclists occur in areas where there are absences of suitable targets such as police officers and other security agents who can apprehend the criminals. As a result, many of them rob and escape without detection or apprehension.

\section{Empirical Review}

Ukwayi, Agaboh, and Michael (2013) tried to understand public perception of the involvement of commercial motorcyclists in crime in Uyo metropolis. Using a sample size of 330 from a sample selected through purposive sampling method, they found that commercial motorcyclists were involved in various criminal activities, such as snatching of valuables and kidnapping. The respondents in the study, however, identified unemployment and greed as major factors that predisposes commercial motorcyclists to crime.

In another study conducted in Pennsylvania, USA by Lee (2004) on the relationship between unemployment and crime. The study applied cointegration tests to detect a casual long relationship between unemployment and crime. It found that there exists long run equilibrium between total crime and various unemployment rates. In addition, Lee (2004) also found evidence of cointegration between total unemployment and property crime, and concluded that young adults are more likely to commit property crimes.

Papps (1999) in his study to determine the relationship between unemployment and crime in New Zealand, used annual data on the level of crime that was obtained from the police department for the period, 1984-1996 for 16 police districts, which included the number of offences reported to the police in each police districts for seven offences groups and the total number of robbers convicted. The type of group offences used by the New Zealand police departments are violent offences, dishonest offences, property damage offences, property abuse offences, sexual offences, and administrative offences. The official measure of unemployment was derived from the Household Labour Force (HLFS), a quarterly survey of statistics from New Zealand. The measure of unemployment selected for this study was the number of people registered as unemployed with the Department of Labour. The study found that unemployment is the sole determinant of crime rate.
The result also indicated that the total rate of crime in New Zealand remains significantly affected by the unemployment rate. Thus unemployment was found to have a significant relationship with violent and property crimes committed.

Udom (2007) asserts that the prevalence of economic crises and the unhealthy structural adjustment policies introduced in Nigeria in the mid 1980's aggravated the problem of the urban poor, which manifested in the drastic loss of jobs and mass retrenchment of workers. It became very expensive to import enough vehicles to cope with the rising demand for means of transportation. The few available retail transporters became elitists in providing transport services by insisting on "drop" rather than mass carriage of passengers. Some of them outrightly refused to drop passengers at their designations. Commercial motorcyclists, therefore, took over the services of taxi drivers and providing and dropping passengers at their destination (Nsa, 2007; Ugboma, 2004). Many unemployed and highly skilled workers who were retrenched became commercial motorcyclists.

Jianhua Xu (2009) examines the relationship between commercial motorcycle taxi and armed robbery. The study was carried out in Guangzhou, Shenzhen and Dongguang areas of China. He relied on three sources of data namely: official police records, observation and interview. He found that motorcycle was important for the daily lives of the people, however it was used as a means of escape by robbers and other criminal offenders. In Nigeria, major urban centres experienced similar situation just like in China where commercial motorcycle operators have been involved criminal activities such as snatching of people's personal effects such as hand bags, money and cell phones, abduction, rape and even murder (Mbalisi and Nzokuru, 2014).

\section{CONCLUSION}

The current state of the Nigerian economy have put unemployment level in double digits and causing criminality to thrive in many urban areas. Many youths including university graduates are roaming the streets in search of temporary, part-time, and full-time jobs, but there seems to be very limited employment opportunities to absorb them. Many local manufacturing companies have simply closed shop because of the security situation and the high cost of running business in Nigeria. Many companies, particularly oil companies have also laid off their 
employees due to dwindling profit associated with glut in the global oil price. This state of the Nigerian economy has forced many jobless youths to become commercial motorcyclists in order to earn a living. However, personal greed and the desire to make quick money have propelled many motorcycle riders to use their motorbikes to rob people of their valuables. This assumed association between commercial motorcycle and crime has caused many states governments to abolish their operation in major urban centres, while others have simply bought tricycles to unemployed youths as part of their empowerment schemes. Since commercial motorcycles have appeared to become an indispensible means of transport in most developing nations including Nigeria, with inefficient means of public transport, we suggest that commercial motorcycle operators should be duly registered by law enforcement agents including taking fingerprints of such operators. Such fingerprints should be stored in a database that is maintained by a special ICT unit in each police departments. This will provide an easy means of identifying, arresting and prosecuting those who use their motorbikes to commit crimes.

\section{REFERENCES}

1) Asekhomo, F.F. and Oisomoje (2013). Ban on Commercial Motorcycle Operations in Benin

2) City, Nigeria: An Appraisal of the Benefits and Business Opportunities. Developing Countries Studies. 3(4).

3) Cohen, L and Felson Marcus (1979) Social Change and Crime Rate Trends: A Routine Activity

4) Approach, American Sociological Review, 44 (4), 1979, pp. 588-608

5) Gbadamosi, G. (2006) Economic Development, Crime and Policing: Global Perspectives. Edited by Frederic Lemieuux, Garth Den Yeyer and Phillip K. Dos. London: MacMillan.

6) Igbo, E.U.M. (1999) Introduction to Criminology. Nsukka: Afro-orbis Publishers

7) Iwarimi Jaja, (2012) Criminology the Study of Crime $\left(4^{\text {th }}\right.$ Edition). Owerri: Springfield .Publishers

8) Jianhu Xu, (2009) The Robbery of Motorcycle Taxi Drivers (Dake Zai) in China: A Lifestyle/Routine Activity Perspective and Beyound. Brit J. CIMINOL 49(4) PP 491-512

9) Kumar, A. (2013) Understanding the emerging role of motorcycles in African cities: A political economy perspective. Sub-Saharan Transport Policy Program. Pp 10.

10) Mbalisi, O. F. and Nzokuru, Joy C. (2014) "Dangers Associated with Commercial Motorcycle Transport Business: Implication for Adult Education in Nigeria". Journal of Education and Practice Vol. 5(37)pp 1-9

11) Sutherland, E. (1947) Principles of Criminology. ( $4^{\text {th }}$ Edition). Philadelphia: Lippincott

12) Papps, K. L. (1999) "Unemployment and Crime: New Evidence for an old Question. Centre for Economic Policy Research, London.

13) Ukwayi, J. K. Agba, A. M. Agaboh and Christopher E. Michael (2013)"'Public Perception of the Involvement of Commercial Motorcyclists in Crime in South-South Nigeria." International Journal of Humanities and Social Sciences, Vol. 2(7).

14) Wikipedia The Free Encyclopedia (2017) Classical School (Criminology). Accessed on September $5^{\text {th }}$ 2017

from https://en.wikipedia.org/wiki/Classical_school_(cri minology) 